\title{
POLYFUNCTIONALITY OF THE ENGLISH QUANTITATIVE WORDS
}

\author{
SVITLAna SHVAchKo \\ shvachko.07@mail.ru \\ Sumy State University, Ukraine
}

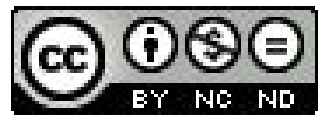

\begin{abstract}
The article in question considers the functioning of quantitative units, their language and speech aspects. Introduction focuses upon the major items of paper - definition of numerals, words of weight and measure, aims, methods of investigation, empiric material applied, evolution modifications, and perspectives of further study.

Key words: quantitative words, numerals, words of weight and measure, polyfunctionality, language and speech aspects.
\end{abstract}

\section{INTRODUCTION}

The metasign quantity refers to units which verbalize the results of cognition by the seme quantity. The allonyms of this type objectivize the arrangement of number and measure groups. By quantitative words I understand the language units semantically charged with the general seme quantity and subsemes number and measure.

Topicality of the research is determined by the modern trend in linguistics to identify the functions of investigated phenomenon at language and speech levels. The paper considers novelty aspects in zone of quantitative words, which have not been scientifically grounded yet (epidigmatic function, approximation at work, processes of evolution and involution of quantitative units).

The objectives of the paper concern the English quantitative word in their etymological background, diasynchronic modifications and polyfunctionality. The attempt has been made to clarify the status of the investigated subject in the lixico-semantic field of quantity, its linguocognitive nature.

The empiric facts have been taken from the authentic English dictionaries and modern English literary texts. The touched upon problem has been analyzed by adequate methods to identify the semantic volume, etymological sources, historic deviation, polyfunctionality and systematic arrangement of researched units.

The different methods are involved to consider the nature of investigated units (in our case - numerals, words of weight and measure). Thus the set of integrated methods are at work here: etymological, definitional, componential, distributionl, contextual, and cognitive. The unvestigated units are diasyncronically studied at language an speech levels.

An attempt has been made to explain the mystery of dichotomy numerals::words of weight and measure in the English language. Touched upon targets 
concern etymological sources and polyfunctionality of the investigated phenomenon. Our working hypothesis reads as follows: the words with identical semes undergo similar tendencies.

\section{HISTORY OF THE ENGLISH QUANTATIVE WORDS}

Quantitative units have their history, the inherent semantic structure and functions. Bearing the nominative function, the words of number implement cognitive function. The semantic evolution of these words reflects main stages of cognition, the study of which is highly relevant today (Shvachko, 2008, p. 6).

Words as polyfunctional units nominate things, concepts, make sentences go, keep memory of the bygone days, make metasigns (ibid, 2008, p. 81). People use words not only in communication but also in investigation. Quantitative words make no exception; they witness the ways people used to cognize the world. Usually they are numerals, which are often referred to as counting numbers, indicating numeration. In remote times these words behaved otherwise, which is proved by the linguistic investigation, by reconstruction of old forms in different languages, by the study of semantic deviations and tendencies. The etymological analysis of number and measure words brings fruitful results. The mentioned analysis brings closer the past times, the mode of life of generations to have gone, their way of thinking, which spans efforts of people in cognizing the Universe.

The English numerals, words of weight and measure are nominated here as quantitative ones as those charged with general seme Quantity and corresponding subsemes Number and Measure. Both groups make the centre of lexico-semantic field of quantity. Numerals come to the forefront for they are used with discrete nouns and as mediators with indiscrete ones. The numerals and words of weight and measure have much in common - both in their history and functioning.

Numeric words are traced in old linguistic forms; nowadays units fulfill nominative, cognitive and epidigmatic (word creating) functions. The English numerals and words of weigh and measure make the subject of this paper. In our investigation attention is being focused upon the common and distinctive properties of the mentioned units in the basic sectors of the semantic field of quantity. The latter includes the language units with integrating seme quantity or its subsemes number, dimension. Hierarchy of this paradigm is represented at morphological, syntactical, lexical and phraseological levels. The basic sectors are those of numerals (counting function) and words of measure and weigh (measuring function). The semantics of these words are formalized in dictionaries by the patterns of the type: five - the number $5, \mathrm{~V}$; six - being one more than five, twice three; acre - a measure of land, 48,40 square yards or about 4000 square meters; ton - a unit of volume for measuring, the displacement of a ship equal to $35 \mathrm{cu} . \mathrm{ft}$; a European measure of capacity for lumber, usually equal to $40 \mathrm{cu}$. ft. (Shvachko, 2008, p. 92).

Deep reconstruction of numeric words claims that binary oppositions were the first to usher in the succession of cognizing stages of number. This is illustrated by diverse data from mythology, legends, folklore, ethnography, archaeology and anthropology, by the semantic modification of the investigated units, their collo- 
cations, universal laws working with different language systems. Binary opposition goes back to the notion of entity on the vector entire $\rightarrow$ binary (dismembered in two) $\rightarrow$ singling out "one": "man and woman", "sky and earth", "light and darkness" (Taranetz, 1999, p. 17).

The names of numbers 1-10 go back to concrete referents: five from finger, ten from toe. Their phenomenal nature is working in successions five $\rightarrow$ fiver, ten $\rightarrow$ tenner, million $\rightarrow$ millionaire. Gradually succeeding concepts of "three, four..." followed on in their verbalization. Scientists assert that counting started with "two". The study of binary opposition gives ground for the pertinent conclusion: antonyms (binary opposition: day - night, light - darkness) preceded synonyms which are of later creation and outnumber antonyms at present.

The late Paleolithic period finds show that people used to count and depict the results of their efforts in drawings. The remnants of the object standards are kept in the treasury of language forms. Some words go back to medieval times and work until now: brace, yoke, fathom, pair, couple.

In the late Stone Age (35 thousand years ago) people marked the results of counting by lines, dots, cycles. It was called Paleolithic Ornament. Then people were afraid of nature and scared off by its discretion. They could hardly overcome the diversity and power of nature while cognizing it. Hunting, cattle breeding and agriculture made people attentive to the phenomena of time and space. The survivals of distant cultures show the difficulties which people overcame considering duality: burial of two twins, the unsplit figures, two goddesses.

Numeric words belong to counting names of discrete things. But in remote times these words were of another nature (Shvachko, 2008, p. 123). This is proved by linguistic investigation, by reconstruction of old forms in different languages, by the study of semantic laws, tendencies, evolution of the paradigmatic units. The etymological analysis of number and measure linguistic signs brings fruitful results in identification the mode of life of of generations to have gone, their ways of thinking.

Numeric words go back to nominal units. Counting as a process embraces both those who count and the things counted. These units fulfill nominative and cognitive functions. By the cognitive function we understand the ability of units to reflect the major miles in the evolution of quantity cognition. The close study of quantitative units reveals their anthropomorphic nature (Anokhina, 2007, p. 6). These words go back to the names of parts of body, of tools used, of things they counted and measured. The common tendencies work both with numeric words and measure units. Cf.: numeric words: dozen, couple, pair, brace, score, one, five, ten thousand, hundred, million, milliard; measure words: ell, span, foot, fathom, yoke, brace, acre, pint, stone, pound, bushel, ton.

The etymological background of words denoting measure and weight is vivid in contrast to numerals, which have their history hidden. For example "ell", "span", "foot", "brace" etymologically go back to the parts of body and their position. Another group (pint, bushel, ton, chaldron) go back to the names of containers in which things were kept. Other measure units (yard, rod, pole, par, stone) go back to the instruments of measuring. Some quantitative words are used both for numeric and measuring assessment (dozen, couple, brace, yoke, score). 
The semantic deviation of quantitative words is stable in metonymic shift: object-name1 $\rightarrow$ quantity $\rightarrow$ object name2. With proper numeric words (numerals) the first link (object name1) is lost with times. Reconstruction of old numeric forms illustrates the derivative nature of first ten numerals which go back to their unquantitative predecessors.

\section{LINGUOCOGNITIVE NATURE OF THE ENGLISH QUANTITATIVE WORDS: POLYFUNCTIONALITY}

The analysis of empiric material proves that polyfunctionality of the subject is at work with nominative and communicative functions. By dictionary definitions the quantitative words carry out the exact number/measure. At the speech level quantitative assessment radically changes: there come exact, approximate and zero markers of quantifications. This scientific novelty is unfortunately not included into the academic process.

The metasign quantity refers to units which verbalize the results of cognition through semes (number, measure). The allonyms of this type objectivize the arrangement of two groups - number paradigm and measure paradigm.

The words do not only nominate things and let communication go, but they are also involved into the investigation process and enable solving the mysteries of language and its inherent properties of systematic arrangement. The latter is implied by comparison, the comparison - by convergence and divergence, convergence and divergence make systems; the ways of their reconstructions are eternal in cognition.

The logic category of quantity is made available due to the analysis of the cognitive nature of the linguistic units which alongside with other semiotic signs make quantification work. It is common knowledge that quantity does not exist independently, singly. It is inherent property of real and imaginative worlds. The cognition of quantity results in some gains of the scientific picture of the world.

Counting as a means of cognition works with linguocreative thinking (Shvachko, 2008, p. 124). The denominal tendency is traced in the constant modifications and semantic deviations. This is verified by the cycles of their evolution: $(\mathrm{N} 1 \rightarrow$ Num $\rightarrow$ N2): five $\rightarrow$ fiver (\$5), six $\rightarrow$ sixer (a team), million $\rightarrow$ millionaire, millionairedom.

The process of lexicalization is objectivized by emergence of set-expressions with numerals. Numeric components yield to nominal ones, quality comes forward: "forty winks", "as thick as two thieves", "seven wonders", "two dogs over one bone". Numerals may be dropped or substituted, the quantitative zero constituents do not influence the general message: "to make two (both) ends meet", "saying and doing are two (different) ways", "as drunk as (seven) lords"; "as cross as (two) dogs over a (one) bone"; "as like as (two) peas".

The numeric words are bifunctional as they are used in above examples type, and in abstract counting of the type "two times two is four", "four divided by two is two". The numeric features are verbalized by monolexical and polylexical units. Phraseological ones do not stand apart, they express quantity (in our case: number) 
- explicitly and implicitly. Empiric material objectivizes the existence of paradigmatic cluster - language quantity field. The latter is bicentered; numeric and measure units constitute its major sectors. Numeric words (numerals) major in it, for they are used with discrete things directly and with indiscrete ones as a team with measure units: "two apples", "three trees"; "two pounds of sugar", "three bushels of coal".

Quasi-words are used not only in the English language: "hickory", "dickory", "dick" (kid's song). The Celtic units "hevera" (8), "devera" (9), "dick" (10) are used in the cowboys` slang (Litvin 2005, p. 203). The archaic units have the tendency to be deleted. Nominal property comes forth in words made by conversion: a thousand people $\rightarrow$ thousands. Bisemy of numerals, i.e., their quantitative and non-quantitative meanings, works time and again on their diachronic vectors: "two or three"; "two upon ten"; "to be in two minds"; "when two Sundays come together".

The category of quantity refers to different areas: it has logical, linguistic and mathematic characteristics. Until now the dual number is implied by two eyes, two legs, left-right side of body, two hands, two arms, moon and sun, sunrise and sunset, day and night. Thus entity and duality have gone their way together but apart from times immemorial. "Duality" as the prominent Ukrainian scholar notes "is associated with matriarchy yielding to patriarchy" (Taranetz, 1999, p. 17). The notion of three is closely correlated with mythology. Slavonic people symbolized by three cycles the god of the Sun implying morning, afternoon and night. In folk-tales there existed three-headed snakes, three kingdoms, three urgent problems, three sons, three efforts and the like. Cognizing is slow in its progress. The number of "four" repeated the evolution of 1, 2, 3 numbers. The Tripol agriculture was four-measure oriented due to the pressing urgency of land measuring. Four components are anthropologically oriented: ahead, behind, left, right; cross image; four-faced god ruling the Universe. Each succeeding number was firstly perceived in terms of "many": "two heads are better than one"; "four eyes see better than two"; "two is company, three is none".

Thus, the words keep history of civilization fresh and open for those people who are not reluctant to get to know it. The explicit markers of the standard units have been lost with numerals. Contemporary numerals present names of abstract quantitative meaning, the proof of their old background is verified by the study of primeval language numerals (1), quantity units of later construction (2), reconstruction of old forms (3), semantic tendencies of relative words (4), their combinability and collocation (5), word-building potentiality (6) and anthropomorphic factors (7).

Just like people, words have their own life stories, sagas of ups and downs. People come and go. Words may stay longer. They are open to modifications - both in their outer and inner structures. By numeric words we mean numerals, their lexical parallel units semantizing "number" - relating to quantitative features of discrete things: "six children", "a dozen books", "a couple of people", "dialogue", "millionaire", "two universities". The liguocognitive story of numerals should not be closed until it is continued by the succeeding moments in their diachronic evolution:

(i) they go back to concrete referents;

(ii) with time they come to function as absolute terms;

(iii) determinologized quantitative words lose their quantitative meaning and become aligned with synonyms, antonyms and stylistic devices; 
(iv) they are working components of phraseological units;

(v) they are known for polyfunctionality (nominative, cognizing, word-building power);

(vi) they are flexible in their semantic deviation (substance $\rightarrow$ quantity $\rightarrow$ quality $\rightarrow$ zero charge);

(vii) they are strong in word building power.

Epidigmatic function is objectivized in particular by emergence of numerals.

Both numerals and denumerals (words made of numeral morphemes) are contextually determined; cognizing is being reflected by exact definite and indefinite marking. The derivative units of secondary nature join different parts of speech. The denumeral nouns, adjectives, adverbs come to the forefront. Syntactical denumeral units yield to them. Denumerals keep the life of their "parents" alive. Moreover, they serve the ground for further evolution, when by conversion they stimulate the life of notional, lexically charged words. Thus, this factor makes vivid the cyclic way of quantitative units. Among the denumeral units each fourth belongs to the syntactic functional words, the status of which is not identified until they are syntactically treated. A proverb says "use soft words but hard facts". The linguistic analysis of denumerals verifies the status of notional and functional units. In our experiment: 1085 examples are notional denumerals, 315 - syntactical formants (in the cluster of 1400 experimented units analyzed in the English literary texts (Shvachko 2008, p. 21).

The "lust for life" of such denumerals like "once", "twins", "teeners", "millionaire", "fortnight" is obvious. The lexeme "one" has great history for it belongs not only to the "family of numeral" but it also "eyewitnessed" the many stages of the English word building. "One" has etymological parallels in the domains of articles, pronouns, nouns and syntactical forms: "once", "only", "alone", "none", "anyone", "someone", "oner (to be the first/a oner at smth)", "oneness", "only if", "when only". The above derivative words look homonymous but they are functionally identified on the syntagmatic level. For example: "Abby hoped this line would make her plan seem the only sensible option" (Kelly, 2003, p. 265). "Only if you help me it will be easier to settle" (Cookson, 2001, p. 76). "Because only he can move Jess from the grief toward happiness" (Sparks, 2012, p. 42). "She wrote not only the text but also selected illustrations" (Steel, 1991, p. 190). "Only then did she realize that her father loved her with all his heart" (Gree, 2002, p. 154).

The linguistic analysis proves that the words with common semes undergo common modifications. The quantitative words undergo the process of evolution and involution. The denumerals mirror syncretism of their predecessors (numerals), initial bisemy. The secondary consructions keep memories of "parents", developing their modifications. At the syntagmatic level the numerals verbalize exact, approximate, and indefinite quantity: numerals in collocations: "by two", "in two ways"; "for about two hours", "a bird or two"; "nine (twenty winks)"; "as cross as (two) dogs over one bone"; the denumerals work likewise in nominative units: "once", "alone", "fourfold", "someone", "fortnight", "oncer" (brother), "oncer" (church visitor).

Numerals and words of weight and measure in language make terminological group which verbalize exactly the quantitative properties of countable and uncountable things. Numerals make measure words function. They count measure units 
and let quantification go. Cf.: (three tons) of sugar, (two yards) of silk. The analyzed subgroups make major centers of lexico-semantic field of quantity. The divergence of these groups consist in the choice of determined units - discrete and indiscrete.

In conclusion, we assume that numeric words and their secondary denumeral formations are polyaspected, polyfunctional and polymodal units. They are highly prolific, prosperous and perspective considering the further investigation in modus of Language Speech and Speech activities. Numerals are marked by syncretism, simultaneous actualization of two semes - "substance" and "quantity". With times "substance" yields to quantity, and the analyzed words convert into genuine terms. Then there works the divergence in speech modus (in contrast to language modus). Both groups are open to shifts: from exact quantity to approximate and zero quantity. The cyclic evolution of investigated units is vivid in the process of lexicalization and gramaticalization on their epidigmatic vectors.

The vistas of this paper consist in identification of conjunction between the obtained results and those to come in future which is indispensable for deepening theory of systematic arrangement of language and its semantic groups on the one hand; for widening scientific world picture on the other hand. Constructive dialogs and discussions are badly needed to solve the problems of the lacunar entropic nature. Practical value of gains obtained awaits application in the educational process.

\section{SOURCES}

Cookson, C. (2001). The Silent Lady. Great Britain: Mackays of Charthem.

Gree, A. (2002). The Dukes's Mistress. Great Britain: Mills and Book.

Kelly, C.(2003). Best of Friends. London: Harper Collins Publishers.

Sparks, N. (2012). The Lucky One. New York: Hatchete Book Group.

Steel, D. (1991). Heart Beat. Great Britain: Bantam Press.

\section{REFERENCES}

Akulenko, V.V. [Акуленко, В. В.], Shvachko, S. О. [Швачко, С. А.], \& Bukreeva, O.I. [Букреева, Е. И.] (1990). Категория количества В современных европейских языках [The category of quantity in the modern European languages]. Kyiv: Naukova dumka.

Anokhina, T.O. (2007). Relating translation techniques to current methodology. In: Humanistic and Pragmatic TEFL. XII International Conference of the Educational Assosiation of Teachers of English to Speakers of Other Languages in Ukraine, April 21-22, 2007. Abstracts. Kyiv: National Academy of Management.

Bolinger, D. (1972). Degree words. Hague, Paris: Mouton.

Bache, C. (1978). The Order of Premodifying Adjectives In Present-Day English. Odense: University Press.

Litvin, F.A. [Литвин, Ф.А.] (2005). Кванторы и слова [Quantitors and words]. In: N. D. Arutyunova [J1] (ed.). Логический анализ языка. Квантификативный аспект языка. Logical analysis of language. Quantificative aspect of language [J2] (pp.201-206). Moscow: Indryuk.

Shvachko, S. О. [Швачко, С.О.] (2008). Квантитативні одиниці англійської мови: перекладацькі аспекти. - Посібник [The quantitative units of the English language: translation aspects. The handbook]. Vinnitza: Nova kniga.

Taranetz, V.G. [Таранець, В.Г.] (1999). Походження поняття числа і його мовної реалізації (до витоків індоєвропейської прамови). - Монографія. - Видання друге. Перероблене и доповнене. [The origin of the concept of number and its linguistic realization (the origins of the Indo-European proto-language)]. Odessa: Astroprint. 